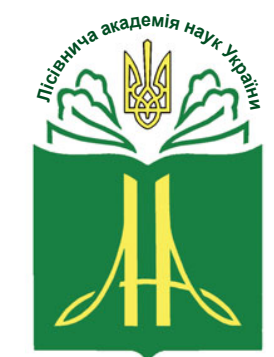

Forestry Academy of Sciences of Ukraine
Наукові праці Лісівничої академії наук України Proceedings of the Forestry Academy of Sciences of Ukraine http://fasu.nltu.edu.ua https://doi.org/10.15421/412031

Article received 2020.05.25

Article accepted 2020.12.28
ISSN 1991-606X print

ISSN 2616-5015 online

@ $₫$ Correspondence author

Yaroslav Fuchylo

fuchylo_yar@ukr.net

v. Hamarnya, Malyn district, Zhytomyr region,
11643, Ukraine

\title{
Вплив технології створення енергетичних плантацій Salix viminalis L. на їx ріст і продуктивність після першого трирічного обороту заготівлі біомаси
}

\author{
Я.Д. Фучило', Б.М. Вокальчук²
}

\begin{abstract}
Оијінено вплив сортових особливостей, схеми та густоти садіння живців на ріст і продуктивність енергетичних плантацій верби прутоподібної (Salix viminalis L.) впродовж двох років другого трирічного обороту заготівлі біомаси в умовах Центрального Лісостепу України. Об 'єктом дослідження були плантації двох сортів - 'Тора'i 'Тернопільська', які висаджені дворядними кулісами з відстанню між рядами 0,75 м, за двох схем садіння живців: відстань між кулісами - 1,5 м (0,75-1,50-0,75 м) та 2,5 м (0,75-2,50-0,75 м). За обох схем садіння, вибравши відповідну відстань між живиями у ряду, було сформовано насадження з трьома варіантами густоти: 12, 15 ma 18 тис. ит. $2 a^{-1}$.
\end{abstract}

Після досягнення дослідними насадженнями трирічного віку, їх надземна частина була зрізана. На початку четвертого року вегетащіï зі зрізаних кущів появились молоді пагони, результати дослідження біометричних показників яких впродовж двох років наведені у иій роботі.

Зі збільшенням густоти садіння на всіх варіантах досліду спостережено зменшення середньої висоти кущуів. Найбільшу середню висоту (6,09 м ) мали рослини сорту 'Тора' за схеми садіння 0,75-1,50-0,75 м та густоти 12 тис. шт. га $a^{-1}$. Виявлено тенденцію до зменщення кількості пагонів у кущі та їхньої висоти за збільшення густоти плантації. Кількість пагонів у кущі дворічних плантацій становила в межах від 4,8 до 6,9 щт. у сорmу 'Тора' та від 5,0 до 8,0 шт. на один куш у сорту 'Тернопільська'.

Максимальні показники продуктивності за два роки $\left(41,7 \mathrm{~m} \cdot 2 a^{-1}\right.$ сухої біомаси) та приросту біомаси впродовж другого року (21,3 m·га су сухої біомаси) зафіксовані в насадженнях сорту 'Тора' за схеми садіння 0,75-1,50-0,75 м i густоти 15 тис. кущів на 1 га. У сорту 'Тернопільська' найвищу врожайність (30,5 m·га') було зафіксовано за тієї ж схеми садіння і густоти на 1 га. За відстані між кулісами 2,5 м найвищу продуктивність дворічної біомаси також мав сорт 'Тора' - 34,0 m·га'. . Максимальна продуктивність сорту 'Тернопільська' становила 23,5 m·га $a^{-1}$ а мінімальна $\left(17,5 \mathrm{~m} \cdot 2 \mathrm{a}^{-1}\right)$ - за максимальної густоти садіння (18 тис. шт. $\left.2 a^{-1}\right)$.

Ключові слова: біомаса; інтенсивність росту; продуктивність біомаси; густота стояння; сортові особливості; висота куща; приріст біомаси; діаметр пагона; схема садіння.

\footnotetext{
Фучило Ярослав Дмитрович - академік Лісівничої академії наук України, доктор сільськогосподарських наук, професор, завідувач кафедри лісівництва та захисту лісу Малинського лісотехнічного коледжу. Головний науковий співробітник Інституту біоенергетичних культур і цукрових буряків НААН України, вул. Клінічна, 25, м. Київ, 03141, Україна. Тел.: +38-067-605-91-41. E-mail: fuchylo_yar@ ukr.net ORCID: http://orcid.org/0000-0002-2669-5176

2 Вокальчук Богдан Миколайович - аспірант Інституту біоенергетичних культур і цукрових буряків НААН України, вул. Клінічна, 25, м. Київ, 03141, Україна. Тел.: +38-067-605-91-41. E-mail: bv753m@gmail.com ORCID: https://orcid.org/0000-0002-7509-4000
} 
Вступ. Обмежені ресурси традиційного палива та зростання попиту на енергію змушують активізувати пошук і використання відновлюваних джерел енергії. Одним із таких носіїв, що дає найкращі результати в умовах європейського клімату, $є$ енергетична біомаса, отримана на плантаціях верби (Salix spp.) з коротким оборотом рубки. Причина полягає в тому, що більшість видів верб дуже інтенсивно ростуть у перші роки, легко розмножуються за допомогою живців і здатні рясно генерувати нові пагони після зрізання надземної частини рослини (Фучило, Сбитна, 2017).

Виробництво біомаси верби характеризується низькими витратами, а сама біомаса - високою теплотворною здатністю та незначними обсягами викидів речовин, що забруднюють атмосферу. Енергетичні плантації верби, як високопродуктивні багаторічні насадження, сприяють зменшенню попиту на деревину з природних лісів, поліпшують стан довкілля, відновлюють виснажені грунти, зменшують інтенсивність ерозійних процесів тощо. Під час удобрення таких насаджень можна утилізувати різні органічні відходи, включаючи осад стічних вод (Adegbidi, Volk, White, Abrahamson, Briggs \& Bickelhaupt, 2001; Labrecque \& Teodorescu, 2001).

Одним із найперспективніших видів для вирощування на енергетичних плантаціях є верба прутоподібна (Salix viminalis L.). Ї̈̈ сорти і гібриди найчастіше використовують 3 цією метою, тому саме за цим видом в Україні закріпилася назва «енергетична верба» (Афонін, Фучило, 2012; Фучило, Сінченко, Мельничук, 2016).

На сьогодні високу продуктивність біомаси для виробництва біопалива забезпечують нові сорти та гібриди енергетичної верби, отримані селекціонерами Швеції (Willow Varietal Identification Guide, 2012). Досвід учених цієї країни підтверджує, що, окрім удосконалення сортового складу, для максимального використання потенціалу енергії росту верб необхідно удосконалювати технологію вирощування, адаптуючи іiі до певних грунтовокліматичних умов (Ecophysiology of Short..., 1992; Christersson, 1986; Mola-Yudego \& Aronsson, 2008).

Важливим елементом технології вирощування енергетичних плантацій $є$ також їхня початкова густота, яку необхідно враховувати в контексті збільшення заготівлі енергетичної біомаси. За результатами досліджень, зменшення густоти садіння рослин верби має негативний вплив на урожай біомаси (Goel \& Behl, 1996). Інші дослідники вказують, що збільшення густоти садіння рослин до понад 20 тис. шт. га ${ }^{-1}$ не призводить до суттєвого зростання виходу біомаси і є недоцільним заходом (Bergkvist \& Ledin, 1998). Результати здійснених досліджень в Україні підтвердили, що показники росту і продуктивності плантацій верби протягом першого трирічного циклу вирощування на вилугуваних чорноземах у більшості дослідних варіантів виявилися вищими саме за початкової густоти 1215, аніж за 18 тис. шт. 'га-1 (Фучило та ін., 2016).
Встановлено, що густота садіння також впливає на кількість пагонів в одному кущі та їхні розміри (Kopp, Abrahamson, White, Burns \& Nowak, 1997), а також на якісні характеристики біомаси, ії структуру та хімічний склад (Bickelhaupt, 2001; Brereton, Ahmed, Sykes, Ray, Shield, Karp \& Murphy, 2015).

На сьогодні в Україні не достатньо даних щодо впливу сортових особливостей, густоти і схеми садіння на продуктивність енергетичних плантацій верби на різних етапах їх вирощування та експлуатації. Саме тому вивчення цього питання є актуальним 3 погляду на необхідність планування обсягів отримання енергетичної біомаси.

Об'єкти та методика досліджень. Об'єкт дослідження - енергетичні плантації Salix viminalis в умовах Правобережного Лісостепу України. Предмет дослідження - вплив елементів технології створення і вирощування на продуктивність енергетичної біомаси насаджень сортів 'Тора' i 'Тернопільська' протягом двох років другого трирічного циклу вирощування.

Мета дослідження - оцінити продуктивність енергетичної біомаси двох сортів Salix viminalis за використання різних елементів технології створення і вирощування на енергетичних плантаціях.

Дослідження виконані впродовж 2018-2019 рр. на дослідному полі Інституту біоенергетичних культур і цукрових буряків НААН України у ДП ДГ «Саливінківське» (с. Ксаверівка Друга Васильківського р-ну Київської обл.), яке розташоване в зоні нестійкого зволоження Правобережного Лісостепу України.

У березні 2018 р., до початку сокоруху, було здійснено зрізання надземної частини трирічних енергетичних плантацій сортів 'Тора' і 'Тернопільська', створених навесні 2015 р. дворядними кулісами 3 відстанню між рядами у кулісі 0,75 м та двома варіантами відстані між кулісами: 1,50 м $(0,75-1,50-$ 0,75 м) та 2,50 м (0,75-2,50-0,75 м). У обох випадках, вибравши відповідну відстань між живцями у ряду, були сформовані насадження з трьома варіантами густоти: 12,15 та 18 тис. шт. га $^{-1}$.

Впродовж трьох років на всіх варіантах досліду сформувались високопродуктивні насадження, середня висота яких у сорту 'Тора' становила від 5,24 до 6,04, у сорту 'Тернопільська' - від 4,14 до 5,57 м. Урожайність сухої біомаси становила, відповідно, 8,4-11,6 та 5,3-9,3 т $\cdot \mathrm{ra}^{-1}$ за рік (Фучило та ін., 2018; Фучило, Сінченко, Вокальчук, 2018).

Після початку вегетації зі зрізаних пеньків почала відростати рясна вербова порость (рис. 1), дослідження біометричних показників якої виконували впродовж наступних двох років.

Дослідження за динамікою біометричних показників і продуктивністю біомаси здійснювали згідно положень апробованих методик (Доспехов, 1985; Фучило, 2011; Фучило та ін., 2018). Статистичний аналіз результатів досліджень виконували на персональному комп'ютері за прикладною програмою Microsoft Office Exel та «Statistika-6» (Ермантраут, Присяжнюк, Шевченко, 2007). 


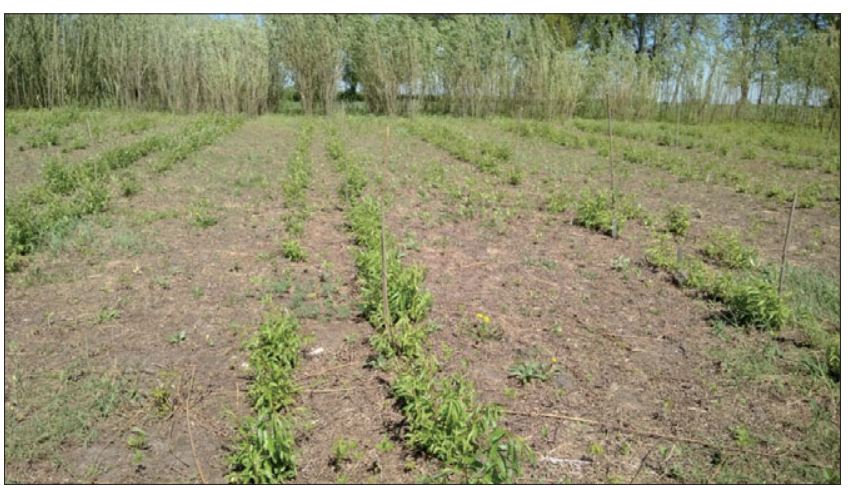

Рис. 1. Загальний вигляд порості верби прутоподібної станом на 30.04.2018 p.

Результати та обговорення. Впродовж першого року вегетації після зрізування трирічної біомаси спостерігався дуже інтенсивний ріст пагонів за висотою (рис. 2, табл. 1).

Найвищі рослини 3 усіх досліджуваних варіантів сформував сорт 'Тора' за схеми садіння 0,751,50-0,75 м та густоти 12 тис. 'га ${ }^{-1}(4,61$ м). Зі збільшенням густоти до 15 та 18 тис. га $^{-1}$ середня висота рослин зменшилась, відповідно, до 4,45 та 4,09 м. Середня висота рослин сорту 'Тора' у варіанті зі схемою розміщення $0,75-2,50-0,75$ м становила 4,21-4,45 м, залежно від густоти стояння рослин.

Найменшими 3 усіх варіантів у перший рік досліджень виявилися рослини сорту 'Тернопільська' за схеми садіння 0,75-2,50-0,75 м та густоти

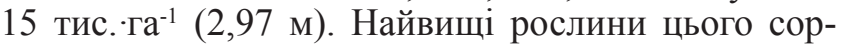
ту було спостережено за схеми садіння $0,75-1,50-$ 0,75 м і густоти 12 тис. шт. га $^{-1}(3,54$ м).

Впродовж другого року вегетації приріст рослин за висотою був помітно менш інтенсивним, але тенденція до зменшення висоти рослин за збільшення густоти садіння залишилася незмінною. Найбільшу середню висоту (6,09 м ) та найбільший середній приріст (1,48 м), як і впродовж першого року, мали рослини сорту 'Тора' за схеми садіння 0,75-1,500,75 м у варіанті $з$ густотою 12 тис. кущів на 1 га. За густоти рослин 15 та 18 тис. шт. га ${ }^{-1}$ висота рослин становила, відповідно, 5,57 та 5,12 м, а середній приріст - 1,02 та 1,15 м.

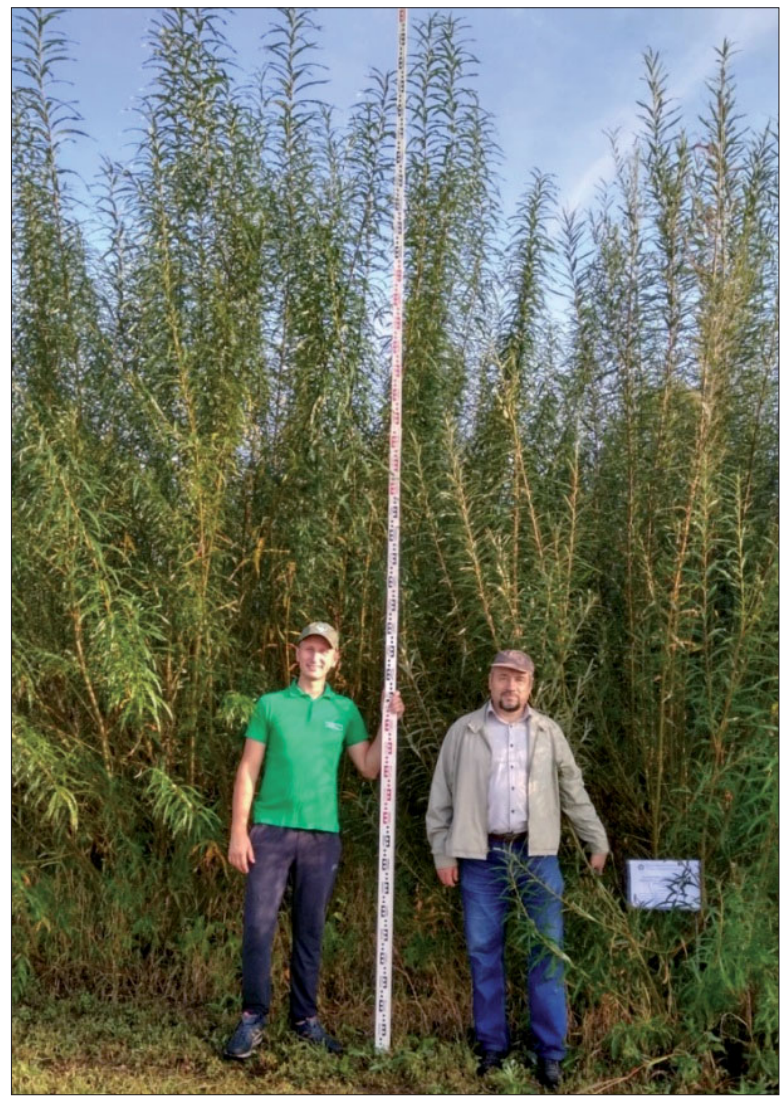

Рис. 2. Загальний вигляд дослідного об'єкту станом на 14.09.2018 p.

Таблиия 1

Середня висота кущів енергетичних плантацій Salix viminalis (м) протягом перших двох років другого трирічного циклу заготівлі біомаси залежно від сортових особливостей, схеми садіння та густоти насаджень

\begin{tabular}{|c|c|c|c|c|c|c|}
\hline \multirow{4}{*}{ Рік } & \multicolumn{6}{|c|}{ Схема садіння } \\
\hline & \multicolumn{3}{|c|}{$0,75-1,50-0,75 \mathrm{м}$} & \multicolumn{3}{|c|}{$0,75-2,50-0,75 \mathrm{м}$} \\
\hline & \multicolumn{6}{|c|}{ Густота рослин, тис. ит. га } \\
\hline & 12 & 15 & 18 & 12 & 15 & 18 \\
\hline \multicolumn{7}{|c|}{ Сорт 'Тора' } \\
\hline 2018 & 4,61 & 4,45 & 4,09 & 4,45 & 4,22 & 4,21 \\
\hline 2019 & 6,09 & 5,57 & 5,12 & 5,6 & 5,24 & 5,01 \\
\hline Приріст, м & 1,48 & 1,12 & 1,03 & 1,15 & 1,02 & 0,80 \\
\hline \multicolumn{7}{|c|}{ Сорт 'Тернопільська' } \\
\hline 2018 & 3,54 & 3,50 & 3,41 & 3,23 & 2,97 & 3,19 \\
\hline 2019 & 4,76 & 4,56 & 4,38 & 4,29 & 4,01 & 3,84 \\
\hline Приріст, м & 1,22 & 1,05 & 0,92 & 1,07 & 1,04 & 0,65 \\
\hline
\end{tabular}

Висота: НІР 05 загальна за роками: 2018-0,21 м; 2019-0,20 м 
У верби сорту 'Тернопільська' більшу висоту встановлено за густоти садіння 12 тис. шт. га $\mathrm{a}^{-1}-$ 4,76 і 4,29 м відповідно. За схеми садіння 0,75$2,50-0,75$ м середня висота рослин у сорту 'Тора' становила від 5,01 до 5,60 м залежно від густоти стояння, а в сорту 'Тернопільська' - 3,84-4,29 м, що значно менше, ніж у варіанті за схеми садіння 0,75 $150-0,75 \mathrm{M}$.

Встановлено, що найбільший вплив на середню висоту кущів мають сортові особливості виду $(69,9 \%)$. Частка впливу густоти становить 13,0 , схе- ми садіння - 9,3, спільна дія цих трьох чинників 0,5 , а дія інших чинників - 7,2\%.

Збільшення густоти садіння рослин негативно вливає на кількість пагонів у кущі. Найбільшу кількість пагонів у перший рік вегетації формували рослини сорту 'Тернопільська' за схеми садіння 0,75-1,50-0,75 м - від 6,9 до 7,8 шт. пагонів на один кущ, залежно від густоти стояння. Найменша кущистість була виявлена у рослин сорту 'Тора' за схеми садіння $0,75-2,50-0,75$ м - від 4,8 до 5,4 шт. пагонів на один кущ (табл. 2).

Таблиия 2

\section{Середня кількість пагонів у кущі одно-дворічних енергетичних плантацій Salix viminalis} залежно від схеми садіння та густоти насаджень, шт.

\begin{tabular}{|c|c|c|c|c|c|c|}
\hline \multirow{4}{*}{ Рік } & \multicolumn{6}{|c|}{ Схема садіння } \\
\hline & \multicolumn{3}{|c|}{$0,75-1,50-0,75$ м } & \multicolumn{3}{|c|}{$0,75-2,50-0,75$ м } \\
\hline & \multicolumn{6}{|c|}{ Густота рослин, тис. шт. га $a^{-1}$} \\
\hline & 12 & 15 & 18 & 12 & 15 & 18 \\
\hline \multicolumn{7}{|c|}{ Сорт 'Тора' } \\
\hline 2018 & 6,6 & 5,4 & 5,2 & 5,4 & 4,8 & 5,2 \\
\hline 2019 & 6,9 & 5,8 & 5,4 & 5,7 & 5,0 & 4,8 \\
\hline \multicolumn{7}{|c|}{ Сорт 'Тернопільська' } \\
\hline 2018 & 7,8 & 7,4 & 6,9 & 7,9 & 6,7 & 4,5 \\
\hline 2019 & 8,0 & 7,5 & 7,0 & 8,4 & 6,9 & 5,0 \\
\hline
\end{tabular}

$\mathrm{HIP}_{05}$ загальна за роками: 2018 - 0,48 шт.; 2019 - 0,29 шт.

За схеми 0,75-1,50-0,75 м і густоти 12 тис. шт. 'га ${ }^{-1}$ сорт 'Тора' формував 6,6 пагонів на один кущ, а за густоти 15 тис. шт. га ${ }^{-1}$ та 18 тис. шт. га ${ }^{-1}$ кількість пагонів була дуже подібною - відповідно 5,4 і 5,2 шт. на один кущ. За схеми садіння $0,75-$ $2,50-0,75$ м рослини сорту 'Тора' також мали найвищий показник кущистості за меншої густоти стояння рослин $-5,4$ шт. на один кущ. За густоти 15 та 18 тис. шт. 'га ${ }^{-1}$ цей показник становив 4,8 і 4,5 шт. на один кущ відповідно.

На другий рік вегетації кількість пагонів у кущі дещо збільшилася внаслідок появи молодих пагонів. Найбільше їх було у рослин сорту 'Тернопільська' за схеми садіння 0,75-1,50-0,75 м - від 7,0 до 8,0 шт. на один кущ. Найменша кущистість виявлена у сорту 'Тора' за схеми садіння 0,75-2,500,75 м (від 4,8 до 5,7 шт. на один кущ). За схеми садіння $0,75-1,50-0,75$ у сорту 'Тора' формувалося від 5,4 до 6,9 пагонів на один кущ залежно від густоти стояння.

Встановлено, що на кількість пагонів у кущі найбільше впливають сортові особливості (40,9\%) та густота стояння рослин $(34,3 \%)$. Фактор схеми садіння мав вплив на рівні $10,7 \%$.

На відміну від кількості пагонів у одному кущі, їх кількість на 1 га зростає за збільшення початкової густоти насаджень. При цьому помітно більшим цей показник виявився за схеми садіння $0,75-1,50$ 0,75 м (рис. 3).
Найбільше пагонів на 1 га сформувалось на плантаціях сорту 'Тернопільська' за схеми 0,75$1,50-0,75$ м - від 96,4 до 125,4 тис. шт. га $^{-1}$. За використання схеми садіння 0,75-2,50-0,75 м у цього сорту показники були дещо меншими - від 90,0 до 103,5 тис. шт. га $^{-1}$ відповідно. Найменшу кількість пагонів на 1 га виявлено в сорту 'Тора' за схеми садіння 0,75-2,50-0,75 м. Вона становила на рівні 83,2 та 72 тис. шт. га $^{-1}$ за густоти 12 і 15 тис. шт. га $^{-1}$. За іншої схеми садіння у клону 'Тора' сформувалося 68,4; 74,3 та 86,0 тис. пагонів на 1 га залежно від густоти стояння рослин. Частка впливу сортових особливостей на кількість пагонів на 1 га становила 52,6 , схеми садіння $-17,2$, густоти стояння $-10,4 \%$. Крім того, сумісна дія цих факторів становила 9,0\%.

Дослідженнями діаметрів найвищих пагонів у кущі (при їх основі) встановлено, що цей показник тісно корелює з висотою (рис. 4) i, як у випадку 3 висотою, спостережено тенденцію до зменшення діаметра пагонів зі збільшенням густоти садіння.

Найбільший середній діаметр пагонів (36,8 мм) зафіксовано у сорту 'Тора' за найменшої густоти (12 тис. шт. га $\left.{ }^{-1}\right)$ і схеми садіння $0,75-1,50-0,75$ м, а найменший (20,3 мм) - у сорту 'Тернопільська' за густоти 18 тис. рослин на 1 га і схеми садіння 0,75-2,50-0,75 м. У сорту 'Тернопільська' найбільший середній діаметр пагона становив 28,7 мм за найменшої густоти садіння (12 тис. рослин на 1 га) і схеми садіння 0,75-1,50-0,75 м. 


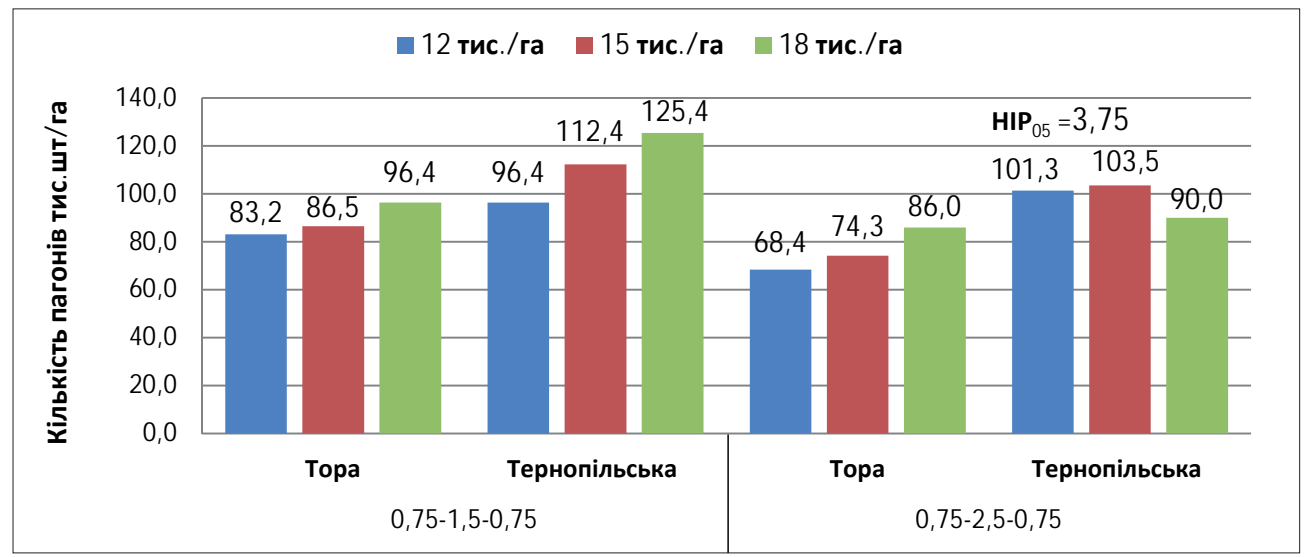

Рис. 3. Середня кількість пагонів на 1 га енергетичних плантацій верби другого циклу вирощування залежно від схеми садіння та густоти насаджень

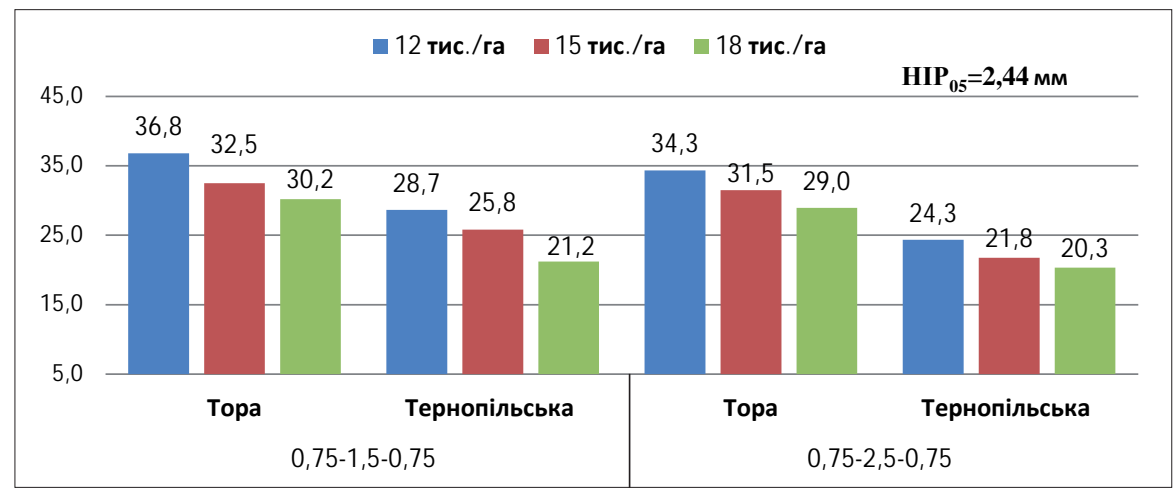

Рис. 4. Середній діаметр пагонів енергетичних плантацій верби другого року вегетації залежно від схеми садіння і густоти насаджень, мм

Дослідження урожайності плантації показали, що вже впродовж першого року вегетації після зрізування надземної частини кущів (2018р.) спостережено значний приріст енергетичної біомаси (табл. 3). Найбільшу продуктивність $\left(20,4 \mathrm{т} \cdot \mathrm{ra}^{-1}\right)$ мав сорт 'Тора' за варіанта 3 густотою 15 тис. кущів на 1 га та схеми садіння $0,75-1,50-0,75$ м, а найменшу $\left(8,7 \mathrm{~T} \cdot \mathrm{ra}^{-1}\right)$ - сорт 'Тернопільська' за схеми садіння 0,75-2,50-0,75 м і густоти 18 тис. рослин на 1 га.

Як i біометричні характеристики рослин, так $\mathrm{i}$ показники врожайності обох сортів були більшими за використання схеми садіння 0,75-1,50-0,75 м.

Таблиия 3

Урожайність енергетичних плантацій Salix viminalis $\left(\mathbf{T}^{\cdot} \mathrm{ra}^{-1}\right)$ впродовж перших двох років другого трирічного циклу заготівлі біомаси залежно від сортових особливостей, схеми садіння та густоти насаджень

\begin{tabular}{|c|c|c|c|c|c|c|}
\hline \multirow{4}{*}{ Рік } & \multicolumn{6}{|c|}{ Схема садіння } \\
\hline & \multicolumn{3}{|c|}{$0,75-1,50-0,75$ м } & \multicolumn{3}{|c|}{$0,75-2,50-0,75$ м } \\
\hline & \multicolumn{6}{|c|}{ Густота рослин, тис. шт. га ${ }^{-1}$} \\
\hline & 12 & 15 & 18 & 12 & 15 & 18 \\
\hline \multicolumn{7}{|c|}{ Сорт 'Тора' } \\
\hline 2018 & 17,3 & 20,4 & 19,6 & 14,1 & 14,9 & 17,7 \\
\hline 2019 & 37,2 & 41,7 & 38,5 & 34,0 & 31,6 & 32,4 \\
\hline Приріст & 19,9 & 21,3 & 18,9 & 19,9 & 16,7 & 14,7 \\
\hline \multicolumn{7}{|c|}{ Сорт 'Тернопільська' } \\
\hline 2018 & 14,2 & 15,2 & 14,1 & 13,1 & 9,4 & 8,7 \\
\hline 2019 & 30,5 & 29,4 & 26,5 & 23,5 & 20,6 & 17,5 \\
\hline Приріст & 16,3 & 14,2 & 12,4 & 10,4 & 11,2 & 8,8 \\
\hline \multicolumn{7}{|c|}{$\mathrm{HIP}_{05}$ загальна за роками: $2018-1,23 \mathrm{т} \cdot \mathrm{ra}^{-1} ; 2019-1,36 \mathrm{т} \cdot \mathrm{ra}^{-1}$} \\
\hline
\end{tabular}


Впродовж 2019-го року (другого року вербової порості - на п'ятий рік існування насаджень), незважаючи на різке зменшення приросту за висотою, приріст біомаси виявився більшим, порівняно 3 першим роком. Максимальні показники продуктивності (41,7 т·га ${ }^{-1}$ сухої біомаси) та приросту біомаси за другий рік $\left(21,3 \mathrm{\tau}^{\circ} \mathrm{ra}^{-1}\right.$ сухої біомаси) зафіксовані у насадженнях сорту 'Тора' за схеми садіння $0,75-1,50-0,75$ м і густоти 15 тис. кущів на 1 га. За густоти 12 та 18 тис. шт. га ${ }^{-1}$ урожайність сухої біомаси становила 37,2 та 38,5 т.га ${ }^{-1}$ відповідно. У сорту 'Тернопільська' найвища врожайність була за густоти 12 тис. кущів на 1 га-

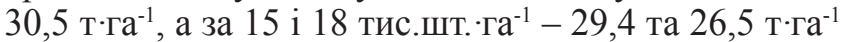
відповідно. За другої схеми садіння також найвищу продуктивність дворічної біомаси мав сорт 'Тора'34,0 т.га ${ }^{-1}$. Максимальна продуктивність сорту 'Тернопільська' становила 23,5 т·га ${ }^{-1}$, а мінімальна $\left(17,5 \mathrm{\tau} \cdot \mathrm{ra}^{-1}\right)$ виявилася за максимальної густоти стояння рослин (18 тис. шт. га $\left.^{-1}\right)$.

Висновки. Сортові особливості та густота стояння рослин суттєво впливають на біометричні показники Salix viminalis, а також на їі урожайність впродовж перших двох років другого трирічного обороту вирощування.

Зі збільшенням густоти садіння у всіх варіантах досліду спостережено зменшення середньої висоти кущів. Найбільшу середню висоту $(6,09$ м) мали рослини сорту 'Тора' за схеми садіння $0,75-1,50$ 0,75 м та густоти 12 тис. шт. 'га⿰ ${ }^{-1}$. Виявлено тенденцію до зменшення кількості пагонів у кущі та їхньої висоти за збільшення густоти плантації. Кількість пагонів у кущі дворічних плантацій становила в межах від 4,8 до 6,9 шт. у сорту 'Тора' та від 5,0 до 8,0 шт. на один кущ у сорту 'Тернопільська'.

Максимальні показники продуктивності за два роки $\left(41,7 \mathrm{\tau} \cdot \mathrm{ra}^{-1}\right.$ сухої біомаси) та приросту біомаси впродовж другого року (21,3 т.га⿰ $\mathrm{a}^{-1}$ сухої біомаси) зафіксовано у насадженнях сорту 'Тора' за схеми садіння 0,75-1,50-0,75 м і густоти 15 тис. кущів на 1 га. У сорту 'Тернопільська' найвищу врожайність $\left(30,5 \mathrm{~T}^{-} \mathrm{a}^{-1}\right)$ було встановлено за тієї ж схеми садіння і густоти на 1 га. За відстані між кулісами 2,5 м найвищу продуктивність дворічної біомаси також мав сорт 'Тора' - 34,0 т·га' тивність сорту 'Тернопільська' становила $23,5 \mathrm{~T} \cdot \mathrm{ra}^{-1}$, а мінімальна $\left(17,5 \mathrm{r} \cdot \mathrm{ra}^{-1}\right)$ - за максимальної густоти садіння (18 тис. шт. 'га $\left.{ }^{-1}\right)$.

\section{Список літератури}

Афонін, О.О., Фучило, Я.Д. (2012). Генетичний потенціал верби прутоподібної (Salix viminalis L.) Середнього Подесення. Науковий вісник НУБіП України, 171 (1), 11-19. [Afonin, A.A., \& Fuchylo, Ya. D. (2012). Genetic potential of basket willow (Salix viminalis L.) of middle stream of the Desna river. Scientific Bulletin of National University of Life and Environmental Sciences of Ukraine of Ukraine, 171 (1), 11-19 (in Ukrainian)]
Доспехов, Б. А. (1985). Методика полевого опыта (с основами статистической обработки результатов исследований). Москва: Агропромиздат [Dospekhov, B.A. (1985). Methodology of field experiment (with the basics of statistical processing of research results). Moskow: Agropromizdat (in Russian)]

Ермантраут, Е.Р., Присяжнюк, О. І., Шевченко, І. Л. (2007). Статистичний аналіз агрономічних дослідних даних в пакеті Statistica 6.0. Київ: ПоліграфКонсалтинг [Ermantraut, E.R., Prisyazhnyuk, O.I., \& Shevchenko, I.L. (2007). Statistical analysis of agronomic pre-historic data in the Statistica package 6.0. Kyiv: PolygraphConsulting (in Ukrainian)]

Фучило, Я. Д. (2011). Плантаційнелісовирощування: теорія, практика, перспективи. Київ: Логос [Fuchylo, Ya. D. (2011). Forest plantations: theory, practice, perspectives. Kyiv: Lohos (in Ukrainian)]

Фучило Я. Д., Сінченко В. М., Мельничук Г. А. (2016). Особливості росту дворічних енергетичних плантацій деяких сортів верби прутоподібної в умовах Центрального Лісостепу. Наукові пращі Інституту біоенергетичних культур $і$ иукрових буряків, 24, 93-99. Київ: ФОП Корзун Д.Ю. [Fuchylo Y., Sinchenko V. \& Melnychuk, H. (2016). Peculiarities of growth of two-year energy plantations of some varieties of willow in the conditions of the Central Forest-Steppe. Scientific works of the Institute of Bioenergy Crops and Sugar Beets. Kyiv: Korzun (in Ukrainian)]. Retrieved from http://nbuv.gov.ua/UJRN/znpicb_2016_24_14

Фучило, Я. Д., Сбитна, М.В. (2017). Верби України: біологія, екологія, використання. Київ: Компринт [Fuchylo, Ya.D., \& Sbytna, M.V. (2017). Willows of Ukraine: biology, ecology, use. Kyiv: Komprint (in Ukrainian)]

Фучило, Я.Д., Сінченко, В.М., Ганженко, О.М., Гументик, М. Я., Пиркін, В. І., Присяжнюк, О. І. ... Ткаченко, А. М. (2018). Методологія дослідження енергетичних плантацій верб $i$ тополь. Київ: Компринт [Fuchylo, Y.D., Sinchenko, V.M., Hanzhenko, O.M., Humentyk, M.Y., Pyrkin, V.I., Prysiazhniuk, O.I. ... Tkachenko, A. M. (2018). The methodology of the study of willow and poplar energy plantations. Kyiv: Komprint (in Ukrainian)]

Фучило, Я.Д., Сінченко, В.М., Вокальчук, Б.М. (2018). Ріст і розвиток енергетичних плантацій верби різної густоти за внесення азотних добрив на вилугуваних чорноземах Центрального Лісостепу. Новітні агротехнологіï, 1 (6). [Fuchylo, Y.D., Sinchenko, V.M., \& Vokalchuk, B.M. (2018). Growth and development of energy plantations of willow of different density with the application of nitrogen fertilizers on leached chernozems of the Central Forest-Steppe. The latest agricultural technologies, 1 (6) (in Ukrainian)]. Retrieved from http://plant.gov.ua/sites/default/files/ fuchylo pdf

Adegbidi, H. G., Volk, T.A., White, E.H., Abrahamson, L. P., Briggs, R. D. \& Bickelhaupt, D.H. (2001). Biomass and nutrient removal by willow clones in 
experimental bioenergy plantations in New York State. Biomass Bioenergy, 20, 399-411. https://doi. org/10.1016/S0961-9534(01)00009-5

Bergkvist, P., \& Ledin, S. (1998). Stem biomass yields at different planting designs and spacings in willow coppice systems. Biomass and Bioenergy, 14, 149156. https://doi.org/10.1016/S0961-9534(97)10021-6

Brereton, N. J. B., Ahmed, F., Sykes, D., Ray, M.J., Shield, I., Karp, A. \& Murphy, R. J. (2015). X-ray micro-computed tomography in willow reveals tissue patterning of reaction wood and delay in programmed cell death. BMC Plant Biol, 15, 83. https:// doi.org/10.1186/s12870-015-0438-0

Christersson, L. (1986). High Technology Biomass Production by Salix clones on a Sandy Soil in Southern Sweden. Tree Physiology, 2, 261-277 https://doi.org/10.1093/treephys/2.1-2-3.261

Ecophysiology of Short Rotation Forest Crops (1992). In C. P.Mitchell, J.B. Ford-Robertson, T. Hinckley, \& L. Sennerby-Forsse, (Eds), Elsevier Applied Sciences, (pp. 1-28). London and New York

Goel, V.L., \& Behl, H.M. (1996). Fuelwood quality of promising tree species for alkaline soil sites in relation to tree age. Biomass and Bioenergy, 10, 57-61. https://doi.org/10.1016/0961-9534(95)00053-4

Kopp, R.F., Abrahamson, L.P., White, E.H., Burns, K.F., \& Nowak, C.A. (1997). Cutting cycle and spacing effects on biomass production by a willow clone in New York. Biomass and Bioenergy, 12, 313319. https://doi.org/10.1016/S0961-9534(96)00077-3

Labrecque, M., \& Teodorescu, T.I. (2001). Influence of plantation site and wastewater sludge fertilization on the performance and foliar nutrient status of two willow species grown under SRIC in southern Quebec (Canada). Forest Ecology and Management, 150 (3), 223-239. https://doi.org/10.1016/S03781127(00)00567-3

Mola Yudego, B., \& Aronsson, P. (2008). Yield Models for Commercial Willow Biomass Plantations in Sweden. Biomass \& Bioenergy, 32, 829-837. Retrieved from https://www.researchgate.net/deref/ http $\% 3 \mathrm{~A} \% 2 \mathrm{~F} \% 2 \mathrm{Fdx}$.doi.org\% $\quad 2 \mathrm{~F} 10.1016 \% \quad 2 \mathrm{Fj}$. biombioe.2008.01.002

Willow Varietal Identification Guide (2012). B. Caslin, J. Finnan, A. McCracken (Eds). Carlow, Ireland: Teagasc\&AFBI

\section{Influence of the technology of planting energy plantations of Salix viminalis L. on their growth and productivity after the first three-year turnover of biomass harvesting}

\author{
Y. Fuchylo', B. Vokalchuk ${ }^{2}$
}

The influence of varietal peculiarities, scheme and planting density of cuttings on the growth and productivity of energy plantations of the basket willow (Salix viminalis) during two years of the second threeyear turnover of biomass harvesting in the Central Forest-Steppe of Ukraine was evaluated. The object of the study were plantations of two varieties: 'Tora', and 'Ternopilska', created by double-row wings, with a row spacing of $0.75 \mathrm{~m}$, with two planting schemes for cuttings: the distance between the wings is $1.5 \mathrm{~m}$ $(0.75-1,50-0.75 \mathrm{~m})$ and $2.5 \mathrm{~m}(0.75-2.50-0.75 \mathrm{~m})$. On both planting schemes, having chosen the appropriate distance between cuttings in a row, stands were formed with three density options: 12,15 , and 18 thousand pieces $\cdot \mathrm{ha}^{-1}$. After the plantings reached three years of age, their aboveground part was cut off. With the beginning of the fourth year of vegetation, young shoots appeared from the cut bushes, the results of the study of which for two years are presented in this article.

It has been studied out that with an increase in planting density, there is a tendency to a decrease in the height of the bushes. The height of annual shoots ranged from 2.97 to $4.61 \mathrm{~m}$, depending on varietal characteristics and planting schemes. The tallest plants of all the variants were formed by the 'Tora' variety with a planting pattern of $0.75-1.50-0.75 \mathrm{~m}$ and a density of 12 thousand pieces $\cdot \mathrm{ha}^{-1}-4.61 \mathrm{~m}$. The smallest height $(2.97 \mathrm{~m})$ was observed in the variety 'Ternopilska' at a density of 15 thousand $\cdot \mathrm{ha}^{-1}$ and a planting pattern of $0.75-2.50-0.75 \mathrm{~m}$.

After the second year of cultivation, the average plant height ranged from 3.84 to $6.09 \mathrm{~m}$, depending on the variety and planting scheme. At the same time, there is a tendency to both a decrease in the number of shoots in a bush and their height with an increase in the density of plantations. The number of shoots per 1 bush ranged from 4.8 to 6.9 pcs. the variety 'Tora', and the variety 'Ternopilska' - from 5.0 to 8.0 pcs.

The maximum yield of two-year biomass (from 38.5 to $41.7 \mathrm{t} \cdot \mathrm{ha}^{-1}$ ) was found in the 'Tora' variety with a planting scheme of $0.75-1.50-0.75 \mathrm{~m}$ and a density

\footnotetext{
Yaroslav Fuchylo - full Member of the Forestry Academy of Sciences of Ukraine, Doctor of Agricultural Sciences, Professor, Head of the Department of Forestry and Forest Protection of Malyn Forestry College. Chief Scientist Institute of Bioenergy Crops and Sugar Beet, National Academy of Agrarian Sciences of Ukraine, 03141, Clinical str., 25, Kyiv city, Ukraine. Tel.: +38-067-605-9141. E-mail: fuchylo_yar@ukr.net. ORCID: http://orcid.org/00000002-2669-5176

Bohdan Vokalchuk - post-graduate student of the Institute of Bioenergy Cultures and Sugar Beet of the National Academy of Sciences of Ukraine, Clinical str., 25, Kiev, 03141, Ukraine. Tel.: + 38-067-605-91-41. E-mail: bv753m@gmail.com ORCID: https:// orcid.org/0000-0002-7509-4000
} 
of 15 thousand $\cdot \mathrm{ha}^{-1}$. With a planting scheme of 0.75 $2.50-0.75 \mathrm{~m}$, this indicator was in the range of 31.6$34.0 \mathrm{t} \cdot \mathrm{ha}^{-1}$ of absolutely dry biomass. The 'Ternopilska' variety has a two-year biomass yield from 17.5 to $30.5 \mathrm{t} \cdot \mathrm{ha}^{-1}$. At the same time, there is a tendency to a decrease in yield with an increase in the density of plantations.

Key words: biomass; varietal peculiarities; planting scheme; planting density; growth intensity; bush height; shoot diameter; biomass productivity.

\section{Влияние технологии создания энергетических плантаций Salix viminalis L. на их рост и продуктивность после первого трехлетнего оборота заготовки биомассы}

\author{
Я.Д. Фучило, Б.М. Вокальчук
}

Оценено влияние сортовых особенностей, схемы и густоты посадки черенков на рост и производительность энергетических плантаций Salix viminalis L. в течение двух лет второго трехлетнего оборота заготовки биомассы в условиях Правобережной Лесостепи Украины. Объектом исследования были плантации сортов 'Тора', и 'Тернопольская', созданные двухрядными кулисами, с расстоянием между рядами 0,75 м при

\footnotetext{
Фучило Ярослав Дмитриевич - академик Лесной академии наук Украины, доктор сельскохозяйственных наук, профессор, заведующий кафедрой лесоводства и защиты леса Миланского лесотехнического колледжа. Главный научный сотрудник Института биоэнергетических культур и сахарной свеклы НААН Украины, ул. Клиническая, 25, г. Киев, 03141, Украина. Тел .:+38-067-605-91-41. E-mail: fuchylo_yar@ukr.net ORCID: http://orcid.org/0000-0002-2669-5176

Вокальчук Богдан Николаевич - аспирант Института биоэнергетических культур и сахарной свеклы НААН Украины, ул. Клиническая, 25, г. Киев, 03141, Украина. Тел.: + 38-067605-91-41. E-mail: bv753m@gmail.com ORCID: https://orcid. org/0000-0002-7509-4000
}

двух схемах посадки черенков: расстояние между кулисами составило 1,5 м (0,75-1,50-0,75 м) и 2,5 м (0,75-2,50-0,75 м). На обеих схемах посадки, выбрав соответствующее расстояние между черенками в ряду, были сформированы насаждения с тремя вариантами густоты: 12, 15 и 18 тыс. шт. га $\mathrm{a}^{-1}$. После достижения насаждениями трехлетнего возраста, их надземная часть была срезана. С началом четвертого года вегетации из срезанных кустов появились молодые побеги, результаты исследования биометрических показателей которых в течение двух лет приведены в данной работе. Установлено, что с увеличением густоты посадки наблюдается тенденция к уменьшению высоты кустов. Высота однолетних побегов составляла от 2,97 до 4,61 м в зависимости от сортовых особенностей и схем посадки. Самые высокие растения из всех вариантов сформировал сорт 'Тора' при схеме посадки 0,75-1,50-0,75 м и густоте 12 тыс. шт. га ${ }^{-1}-4,61$ м. Наименьшая высота (2,97 м) наблюдалась у сорта 'Тернопольская' при густоте 15 тыс. шт. 'Га⿰ ${ }^{-1}$ и схеме посадки 0,752,50-0,75 м.

После второго года выращивания средняя высота растений составила от 3,84 до 6,09 м в зависимости от сорта и схемы посадки. При этом наблюдается тенденция как к уменьшению количества побегов в кусте, так и их высоты при увеличении густоты плантаций. Количество побегов на один куст составило от 4,8 до 6,9 шт. у сорта 'Тора', и от 5,0 до 8,0 шт. - у сорта 'Тернопольская'.

Максимальная урожайность двухлетней биомассы (от 38,5 до 41,7 т.га ${ }^{-1}$ ) оказалась у сорта 'Тора' при схеме посадки 0,75-1,50-0,75 м и густоте 15 тыс. шт. га $^{-1}$. При схеме посадки 0,75-2,50-0,75 м этот показатель был в пределах 31,6-34,0 т.га ${ }^{-1}$ абсолютно сухой биомассы. У сорта 'Тернопольская' урожайность двухлетней биомассы составила от 17,5 до 30,5 т га ${ }^{-1}$. При этом наблюдается тенденция к уменьшению урожайности при увеличении густоты плантаций.

Ключевые слова: биомасса; сортовые особенности; схема посадки; густота посадки; интенсивность роста; высота куста; диаметр побега; продуктивность биомассы. 